\section{The Misunderstood Role of Foreign Language Departments as Integrators of Knowledge Across Disciplines}

\author{
Troy B. Wiwczaroski \\ University of Debrecen, Centre of Agricultural Sciences, \\ Faculty of Agricultural Sciences, \\ Centre of Technical Languages Instruction, Debrecen
}

\begin{abstract}
SUMMARY
Special purpose language courses have always pushed the boundaries that set them apart from, for instance, courses offered in a business department. When we as foreign language teachers enter the special purpose language classroom and begin to explore such areas as ecology, agriculture, biology, mathematics or even law, we inevitably have had to immerse ourselves in those disciplines, in order to be effective. Foreign language departments, like those from any other field of academia, are continually developing courses with cross-disciplinary topics which challenge the competence of our staffs. However, my experience tells me that our ability as language teachers to integrate knowledge from across the disciplinary spectrum is misunderstood, mistrusted and under-exploited. This article explores this unused, and sometimes undiscovered, potential.
\end{abstract}

The Agritechnical Languages Teaching Center (ALTC) offers two semesters of 'technical language' to every student enrolled at Debrecen University's Agricultural Science Center, as the core curriculum requirements dictate. Under the rubric 'technical language', I refer to special purpose language classes in either business or agriculture. Each student has the right to choose which option best suits an individual need. These courses are available to students who have passed a comprehensive examination (i.e. Szigorlat) in general language, given in order to try to ensure that the student entering the technical language classes meet a minimum intermediate level target sufficient for reading, listening, writing and discussing introductory to normative level business or agricultural materials.

For many years, the ALTC has also offered a minor in technical translation. In brief, this course includes training in special purpose languages such as law, business, ecology, culture and civilization and agriculture, with added elements of computer science, biology, genetics, political science and sociology. Students also receive rigorous training in academic and scientific writing. This list of subject areas is left incomplete, and on purpose.

Recently, the ALTC added a second minor in professional language communication. Focal points of training include classes in business, marketing, professional written and oral communication skills, cross-cultural communication, environmental protection and regulation, law and computer science. This list is also left incomplete, and, once again, purposely.

In either minor, language teachers have been doing all the teaching, as there exists, as yet, no inclass co-teaching with colleagues from other departments. This situation is regrettable, because both we as educators and the students we teach could benefit greatly from such cooperative ventures. Therefore, as no such real cooperation takes place in the classroom, language teachers involved in special purpose language teaching in programs such as those mentioned above are forced to expand their competencies to the extent where they can provide their students with interdisciplinary instruction without subject specialist support. Indeed, we have been faced with such tasks for long years now; however, the time comes when one is faced with the question of whether this is best of all possible conditions for the student.

For the purposes of best educating our students, ideally we would welcome closer cooperation with our colleagues in the larger university community. Nevertheless, to a great degree, we as foreign language teachers can and are doing a better job at teaching subject matter from other disciplines than many colleagues outside our departments might suppose. My claim is well supported by the wide range of career developmental activities colleagues in foreign language teaching have been immersing themselves in, especially over the second half of the 1990s. University language departments already have experienced staff available to teach such special purpose languages as business, marketing or ecology. As only one example, teachers of technical translation may possess a working knowledge of special language vocabulary and phraseology from across a wide spectrum of disciplines. Some are even highly specialized in the language and specific jargon of one particular field; so much so in fact, that they can understand and properly discuss subject matter from their specialization at great depth. I do not argue that a language teacher can handle research in quantum physics or microbiology at the level of a physicist or biologist, but a well-read, highly motivated colleague may well handle subject material from general biology on an introductory or intermediate level in order to be able to teach and explain it with great acumen. If we raise the examples of business language or especially marketing, then I would argue that a well-prepared language teacher can even go a notch or two higher.

Departments are also active not only in textbook production which integrates topics from other disciplines, but in the design and running of new, state accredited technical language testing systems. ${ }^{1}$

${ }^{1}$ I need refer only to those developed and accredited by colleagues in the language department at Szent István University, in Gödöllő, 
These examinations cover areas such as business, ecology, plant protection and political science, to name but a few examples. Teaching faculty are publishing articles in recognized journals, organizing academic/research symposia, conferences and congresses, and giving presentations when these are held. Areas they cover not only discuss normative subjects from the arts and sciences, but also include more recent trends, such as cross-cultural and global sociological studies. In short, language teachers are already involved in activities which have impact on curricula and course development, student development and learning outcomes, as well as the employment market.

Regardless of our competencies as colleagues or our professional activities, foreign language departments, despite all their efforts to evolve to fit into the larger academic world, still find themselves to be the 'foreign element' in their faculties. Let us face facts: colleagues outside our departments do not know where we fit into the big picture. This absence of understanding for our true value to student development is grounded in bad tradition, our own colleagues' lack of doctorates (which places us outside the mainstream of traditional academia in the first place), and a generally prevalent disrespect for what we can do for the quality of education as a whole. ${ }^{2}$

Despite the difficulties of the present state of affairs, there is a long-standing tradition which we are already on the road to joining. A sharper focusing of our philosophy of our mission as language teachers might assist us to complete the jump from being seen to be an alien body in the academic organism to becoming a full-fledged, functioning part of it. Almost a decade ago, colleagues abroad began to set themselves to just such a task in earnest. Johnston and Edelstein (1993), for example, raised the call for more internationalized and culturally diverse curricula. As Wieshofer (1995) discusses, language departments joined this call by expressing their own want to build more "content" into their courses (see Musemeci, 1993; Swaffar, 1993). This movement strengthened over the $1990 \mathrm{~s}$, further focusing on content and discipline-based instruction. ${ }^{3}$ The goal of all these efforts culminated in foreign language departments' integrating faculty members from other disciplines and taking their own instruction out of their own departments and

which provide an excellent opportunity for targeting foreign language education in business and agricultural language to a broad base of students, with the added plus that they may earn an accredited technical language examination certificate which will also serve in fulfilling the foreign language examination requirements of the Education Ministry for obtaining their diplomas. See Tóth "Felmérés" and Vas "Strategic".

${ }^{2}$ Some similarities exist between Hungarian colleagues' experiences and those of American faculty. See Lange "Curricular", 12-16.

${ }^{3}$ See bibliography below and compare to Wieshofer "Humanities", 16. 'grafting' it onto courses run in others. ${ }^{4}$ (See Adams, 1996; Wieshofer, 1995) Since the mid-1990s, there has been a nationwide shift in curriculum design in the United States, called 'languages across the curriculum'. Adams (1996) differentiates between this movement and the general move to contentbased teaching foreign language departments have been striving for the previous decade or so. (9ff.) The key new element here is the integration of special purpose languages into classes run outside the actual foreign language department.

\section{HOW LANGUAGE TEACHERS CAN CONTRIBUTE}

This is but one way in which our contribution to the general improvement of education may come into play. As Adams (1996) has summarized, there are a number of critical issues which necessarily raise debate on the effectiveness of language across curriculum programs; however, some of the questions he has analyzed have proved to lead to answers that are healthy food for thought for our situation here in Hungary. For example, the use of courses in special purpose language as expansions of classes offered in non-foreign language departments can dramatically enhance not only the student's capability to perform in a target language, but also enrich learning of the subject matter in a way that could never be achieved in a monolingual setting. This is because the students may

- gain exposure to new outlooks not prevalent in their own culture,

- $\quad$ synthesize their former attitudes to those attitudes the new, foreign texts provide, into an original hypothesis or point-of-view,

- learn about research unavailable in their native languages,

- be challenged to explore a subject more in depth, due to the comparisons they can make between texts in their native language and the foreign language materials,

- actually learn more due to the challenge of having to strain their way through the foreign language texts, due to the depth of processing. ${ }^{5}$

As Wieshofer (1995) shows, students with two years' preparatory language study are ready to handle authentic materials on some basis. She writes that her

\footnotetext{
${ }^{4}$ Generally, colleagues from other departments co-teach special purpose language classes with their foreign language teaching colleagues. What I am pointing to is the argument that some in language teaching feel that this working relationship sometimes creates a climate of understanding in the student body in which the 'language teacher' has to bring in an 'expert' to 'do the teaching for them'. By also sending language teachers to co-teach courses in other departments, this unfortunate misunderstanding of the teachers' partnership and cooperation changes. This need to change the reception of the status of the foreign language teacher within the minds of students and colleagues is the focus of the entire paper, therefore, the need to make this point.

${ }^{5}$ See also Feketéné "A (szak)nyelvi”.
} 
students demonstrated that they are "able to read, analyze, interpret, and discuss authentic texts if those texts have been carefully selected ... and if students have received proficiency-oriented instruction in reading, listening, speaking, and writing."(19) My department's technical translation course provides exactly the same level of preparation over the same amount of time, and I am confident that our students can properly handle authentic texts from a majority of subjects from across the disciplines in an 'extension' course team taught by a foreign language and subject specialist faculty member.

I would go one step further than Adams (1996) and Wieshofer (1995), and argue that syllabus design, if done in a task-based manner, can even facilitate that less prepared students can achieve acceptable knowledge transfer from subject matter from a given academic discipline into a foreign language class. In fact, language textbook writers have been incorporating task-based exercises using materials from a wide range of subjects into their textbooks, on even the most introductory levels, for decades. Such subjects include e.g., business, agriculture and EU-related topics on the impact of legal statutes, rural development and tourism.

\section{SPECIFIC COMPETENCIES OF LANGUAGE TEACHERS IN CROSS-DISCIPLINARY SKILL/TASK TEACHING}

By modifying Bloom's Taxonomy of Educational Goals (1956), I can illustrate how language teachers are competent to teach across disciplinary boundaries. The lowest block of goals Bloom sets are KNOWLEDGE OF FACTS, DEFINITIONS, RULES, METHODS, and THEORIES. In my experience, even first year university language students can, with proper assistance, meet each of these goals with a lower-intermediate text. Once the students have been introduced to a text, tasks teachers can use to measure understanding of content include asking for basic definitions or descriptions, lists (e.g., brainstorming exercises), identifications and/or matching, and the writing of an opinion or statement. Possible assignments for achieving these goals may include identification exercises, quizzes, or short-answer writing of 1-4 sentences. Intermediate-level students are able to handle work on Bloom's second classification level, namely, they can demonstrate a COMPREHENSION OF RELATIONSHIPS BETWEEN FACTS. Teachers can have their students explain how two or more facts or observations relate or even narrate events from a source text. Other tasks might include those relating to cause and effect, classification of knowledge, giving descriptions or explanations, making generalizations, restating subject matter in their own words, and summarizing in brief.

Thus far, I think any colleague might readily agree that a language teacher can more than handle authentic texts from across the disciplines in their courses on an everyday basis, without any question of competency from outside our own field. There remain, however, tasks that colleagues both here and abroad would argue rather belong in a team teaching setting, in order to ensure a high level of subjectspecific performance. Nonetheless, some of the following tasks may be taught by the language teacher without the assistance of a colleague from outside the foreign language department, as long as the instructor in question demonstrates subject competency and the ability to handle student questions about it. Which- ever method one chooses, the secret to success lies in proper preparation of the target group before demanding students perform tasks from the higher taxonomic categories Bloom defines. ${ }^{6}$

Below, I suggest a combination of assignments and tasks that may be used to meet the learning objectives Bloom outlined in his Taxonomy. Curriculum and syllabus development of some courses may need to consider which activities the average language teacher may realistically do alone with their students, and which may need to be done with the assistance of a colleague who is an expert in the discipline in question. Judgments concerning whether a colleague in language teaching is competent to perform or not to perform specific tasks are individual-specific, and I therefore will not attempt to set any standards for making such decisions. I, in no way, am suggesting that some colleagues might not be capable of performing some of the tasks below. Rather, I am suggesting activities as average foreign language teaching colleague might use to target specific learning objectives successfully in their classes.

To use one example of how a special purpose language course at a Hungarian university may use this table, I refer to the content of the Professional Language Communicator's Course offered in my own department. Students in the first semester of this four semester minor course must apply learning to new situations by giving, e.g. a professional presentation to convince. This is the assignment I recommend to develop the competency in level one, as it incorporates tasks aimed at having the students use:

\footnotetext{
${ }^{6}$ Wieshofer writes on how the teacher should prepare the class, in order for these 'higher' activities to work: "With the help of study guides, through pre-reading activities, skimming, scanning, vocabulary exercises, questions, and glossaries, the students are introduced to the authentic text, and are made to understand its most important ideas, and are prepared to discuss it with the discipline teacher and foreign language teacher in the foreign language component class." (19).

${ }^{7}$ By this, I mean what is termed a lektorátus. Some Hungarian universities have Applied Linguistics departments, in which the members of their staff have scientific degrees and the accompanying status, e.g., positions as assistant and associate professors. My paper targets those without Ph.D.s and not working in such departments. I make the distinction because it has been my own personal experience that those language teachers who have such a status enjoy a much more accepted climate with their colleagues form other departments, especially as refers to competencies to teach special purpose subject matter.
} 
- analogy,

- demonstration,

- illustration,

- prediction and

- the formulation of a solution.
Combined, these tasks may lend greater authority to the spoken word, and strengthen the student's command of those oral skills they will need in their later professions, in order to convince a critical listener to adopt a new way of thinking.

Adaptation of Elements from Bloom's Taxonomy, Targeting Development of Special Purpose Language Competencies by Identifying Useful Assignments and Tasks

\begin{tabular}{|c|c|c|}
\hline BLOOM'S TAXONOMY & POSSIBLE ASSIGNMENTS & POSSIBLE TASKS \\
\hline $\begin{array}{l}\text { LEVEL ONE } \\
\text { APPLICATION OF LEARNED } \\
\text { INFORMATION TO NEW AND } \\
\text { CONCRETE SITUATIONS, PROBLEM- } \\
\text { SOLVING }\end{array}$ & $\begin{array}{l}\text { APPLICATION OF FAMILIAR } \\
\text { INFORMATION TO A NEW SITUATION }\end{array}$ & $\begin{array}{l}\text { ANALOGY, APPLY, CALCULATE, } \\
\text { DEMONSTRATE, EXPERIMENT, } \\
\text { ILLUSTRATE, MEASURE, PREDICT, } \\
\text { SHOW, SOLVE }\end{array}$ \\
\hline $\begin{array}{l}\text { LEVEL TWO } \\
\text { ANALYSIS OF INFORMATION INTO } \\
\text { COMPONENT PARTS, IDENTIFYING } \\
\text { CAUSAL RELATIONSHIPS, LOOKING } \\
\text { BENEATH GENERALIZATIONS } \\
\end{array}$ & $\begin{array}{l}\text { EXPLAIN HIDDEN MOTIVES OR FORCES, } \\
\text { IDENTIFY PATTERNS }\end{array}$ & $\begin{array}{l}\text { DIAGRAM, ANALYZE, BREAK DOWN, } \\
\text { DISTINGUISH, INFER, RANK }\end{array}$ \\
\hline $\begin{array}{l}\text { LEVEL THREE } \\
\text { SYNTHESIS OF FAMILIAR PIECES OF } \\
\text { INFORMATION INTO A NEW WHOLE }\end{array}$ & $\begin{array}{l}\text { PRESENT A UNIFIED PICTURE OR } \\
\text { ANALYSIS, DRAWING ON VARIOUS } \\
\text { TOPICS STUDIED }\end{array}$ & $\begin{array}{l}\text { COMBINE, CREATE, DESIGN, } \\
\text { INTEGRATE, PLAN, REARRANGE, } \\
\text { SUBSTITUTE, SUGGEST }\end{array}$ \\
\hline $\begin{array}{l}\text { LEVEL FOUR } \\
\text { EVALUATION BASED ON INFORMED } \\
\text { OPINION, USE OF VALUES TO ASSESS } \\
\text { DATA, EMPHASIZING } \\
\text { REASONABLENESS RATHER THAN } \\
\text { RIGHT AND WRONG }\end{array}$ & $\begin{array}{l}\text { SELECT AND JUSTIFY THE BETTER e.g. } \\
\text { STRATEGY, APPROACH, THEORY }\end{array}$ & $\begin{array}{l}\text { ASSESS, COMPARE, CONTRAST, } \\
\text { CONCLUDE, CONVINCE, DECIDE, } \\
\text { EXPLAIN, INTERPRET, JUDGE, } \\
\text { JUSTIFY, RECOMMEND, SUPPORT }\end{array}$ \\
\hline
\end{tabular}

An example of an assignment we use in this course that targets level two is a 6-week workshop in negotiation theory, followed by a 5-week cycle of negotiation activities in groups. The students receive detailed negotiation worksheets, and also write a report of how the negotiation went in class. In both assignments, students must identify patterns in argumentation that worked or failed, and analyze how and why. Furthermore, the worksheet requires that the groups, in preparing for the actual negotiation, rank objectives, use SWOT analyses and needs analyses.

The outcome of these activities takes the student to level three-type activity, as the final report must synthesize the case on which the negotiation is based, as well as the successes/failures of the group's work. This report must also conclude with (a) suggestion(s) of how the negotiation should have been done better.

Level four activity used in the course develops from lecture and discussion material, which exposes the students to strategies for evaluating, e.g., the proper content of business correspondence or curriculum vitae. They must select and reject content, strategize its improvement, assess it, explain their assessments, interpret these assessments, justify them and recommend the document's final form.

My examples are given only to demonstrate how I have used the table above to ensure step-by-step development of learning objectives in a course to which I contribute. Departments across the country employ similar tools and tasks in other special purpose courses. The true meaning of my use of the table above lies in what it also reflects: the depth in competency our colleagues have developed in areas non-language teaching colleagues are unaware we use in our classrooms everyday. If we can demonstrate our usefulness to these colleagues, $\mathrm{we}^{8}$ might be able to better integrate our courses into those run in other programs across our campuses. Such activity not only raises our profile, but might go a long way in better ensuring job security in the years to come.

In conclusion, language classes offer students a wide variety of educational tools, of which I have provided examples of how only some of the limitless possibilities and tools available are being used today, and may be used in the future. Similar activities not only challenge students to learn about a subject area in another language; they can also perhaps leave a more lasting impression of the material offered on their memories than it would, had they read the same material in their own language. My argument is based on the intensity of concentration a foreign language special purpose language text demands of the student.

When language teachers work together with colleagues from various disciplines, the students are better prepared to meet the challenges of today's globally impacted world, whether this impact affects research, business, or administrative activities. This

\footnotetext{
${ }^{8}$ Again, I refer here to lektorátus - type departments.
} 
achievement comes about by the process Adams (1996) refers to as 'consolidation'.(12) Armed with the requisite level of background knowledge, an inquisitive mind and, furthermore, with the power of the motivation to be successful after graduation, the interested student can utilize a language competency to probe complex issues in discussion and written formats in a target language. Because the student is restricted to using a language other than their native tongue for expression, with a good introduction to the fundamentals of good writing and logical communication skills, the learner will have to study a given material more carefully before the process of formulating their own thoughts can begin. I think that my colleagues in other disciplines can well recognize how this is also a powerful tool in their own hands: they can, for example, present their own research in class, and demonstrate through the medium of language how it integrates, responds to, or builds on that being done in a specific country, region or, with for example English as a foreign language, internationally.

But whether we as language teachers decide to work independently of or with our colleagues across the faculties, we need to always keep in mind that we must first organize our syllabi according to deliberated decisions about how to develop the student properly. We should carefully consider organizing the progression of our teaching activities from easy to challenging to difficult, by using such taxonomies as Blooms, or the one I modified above. By using clear objectives and realistic intermediate targets to ensure progress can be achieved, our impact across disciplines will be measurable, manageable, and able to be documented. Our results will become visible to our colleagues and administrators and, therefore, we can prove our worth and our right to an equal position among the departments in our university faculties.

\section{IRODALOM}

Adams, T. M. (1996): Languages Across the Curriculum: Taking Stock. ADFL Bulletin, 28. 1. 9-19.

Bloom, B. (1956): Taxonomy of Educational Objectives: The Classification of Educational Goals. Handbook 1, Cognitive Domain. Longmanns, Green, New York and Toronto

Edwards, J. (2001): Languages and Language Learning in the Face of World English. ADFL Electronic Bulletin 32. 2. $<$ www/docs/adfl/bulletin/V32N2010.htm>

Feketéné Silye, M. (2001): A (szak)nyelvi kompetenciák és a globális munkaerő piaci elvárások kapcsolata. XI. Magyar Alkalmazott Nyelvészeti Kongresszus

Grosse, C. U.-G. M. Voght (1991): The Evolution of Languages for Specific Purposes in the United States. Modern Language Journal, 19. 181-95.

Johnston, J. S. Jr.-R. J. Edelstein (1993): Beyond Borders: Profiles in International Education. Washington: Assn. of Amer. Colls. and Amer. Assembly of Collegiate Schools of Business

Kramsch, C.-S. McConnell-Ginet (1992): Text and Context: Cross-Disciplinary Perspectives on Language Study. Lexington, Heath

Krueger, M.-F. Ryan (1993): Language and Content: Disciplineand Content-Based Approaches to Language Study. Lexington: Heath

Lange, D. L. (1994): The Curricular Crisis in Foreign Language Learning. ADFL Bulletin, 25. 2. 12-16.
Musemeci, D. (1993): Second Language Reading and Content Area Instruction: The Role of Second Language Reading in the Development of Communicative and Subject Matter Competence. Krueger and Ryan, 169-79.

Sudermann, D. (1992): Foreign Language and Liberal Studies: Toward and Equal Partnership. ADFL Bulletin, 24. 1. 40-45.

Swaffar, J. (1993): Constructing Tasks for Content Classes: The Case for Generative Iteration. Kruegher and Ryan, 181-200.

Swaffar, J. (1999): The Case for Foreign Languages as a Discipline. ADFL Bulletin, 30. 3. 6-12.

Tóth, I. (2001): Felmérés a szaknyelvtanulással és szaknyelvi tudással kapcsolatos nézetekröl. Szaknyelv és Szakfordítás. Tanulmányok a Szent István Egyetem Alkalmazott Nyelvészeti Tanszékének kutatásaiból. Dróth, J. (ed.) SZIE GTK Gödöllő, 9-17.

Vas, J. (2001): Strategic Planning in Service Marketing. Szaknyelv és Szakfordítás. Tanulmányok a Szent István Egyetem Alkalmazott Nyelvészeti Tanszékének kutatásaiból. Dróth, J. (ed.) SZIE GTK Gödöllő, 24-35.

Vas, J.-Tóth, I.-GZ. Szabó, J. (2001): Languages Examination Centre Accreditation material, Vols. I-VI.

Wieshofer, I. (1995): The Humanities Come Alive: Linking Languages to Other Disciplines. ADFL Bulletin, 27. 1. 16-19.

American Council on the Teaching of Foreign Languages (1995): Languages Across the Curriculum: A Post-Secondary Initiative. ACTFL Newsletter, 8. 1. 5-8. 